\title{
Pendampingan Manajemen Tatakelola Gula Jawa Jahe Familo Dukuh Ragayudan RT 02 RW 02 Desa Bocor Kecamatan Bulus Pesantren Kebumen Jawa Tengah
}

\author{
Management assistance and governance of Familo's Ginger Javanese Sugar in Dukuh \\ Ragayudan RT 02 RW 02 Bocor Village, Bulus Pesantren District, Kebumen, Central Java
}

Rahmadi Yotenka ${ }^{1}$
Muhaimin ${ }^{2 *}$
Muhammad Muhajir 1
1Department of Statistics, Universitas
Islam Indonesia, Sleman, Special
Region of Yogyakarta, Indonesia
2Study Program of Chemistry
Education, Universitas Islam
Indonesia, Sleman, Special Region of
Yogyakarta, Indonesia
"email: muhaimin@uii.ac.id
Kata Kunci
Gula Jawa
Pelatihan
Pendampingan
e-Commerce
Keywords:
Palm sugar
Training
Accompaniment
e-Commerce

\begin{abstract}
Abstrak
Tujuan pengabdian kepada masyarakat ini adalah untuk meningkatkan manajemen dan tata kelola home industry Gula Jawa Jahe Familo melalui pelatihan dan pendampingan manajemen pemasaran dengan sistem $e$ commerce. Program kegiatan pengabdian kepada masyarakat dilaksanakan melalui beberapa tahapan, yaitu tahapan persiapan, tahapan pelaksanaan serta tahapan evaluasi. Hasil yang dicapai melalui kegiatan ini adalah peserta dapat memasarkan produk usahanya memalui sistem e-commerce secara optimal.
\end{abstract}

\begin{abstract}
This community service aims to improve the management and governance of the home industry of Familo's Ginger Javanese Sugar through training and mentoring marketing management with ecommerce systems. The program of community service activities is carried out through several stages, namely the preparatory stage, the implementation stage, and the evaluation stage. The results achieved through this activity are participants be able to marketing their products by e-commerce system optimally.
\end{abstract}

(C) 2020 Rahmadi Yotenka, Muhaimin, Muhammad Muhajir. Published by Institute for Research and Community Services Universitas Muhammadiyah Palangkaraya. This is Open Access article under the CC-BY-SA License (http://creativecommons.org/licenses/by-sa/4.0/). DOI: https://doi.org/10.33084/pengabdianmu.v5i3.1176

\section{PENDAHULUAN}

Sumber daya alam di lingkungan keluarga sebagian besar dapat diubah menjadi kegiatan ekonomi yang produktif dengan modal yang kecil (Tambunan, 2002; Prihatin, 1997). Usaha home industry di pedesaan Indonesia terbukti merupakan penyangga perekonomian masyarakat karena kegiatannya menyentuh langsung kebutuhan masyarakat, terutama rakyat kecil dan terbukti kuat dalam menghadapi badai krisis ekonomi (Sulistyo, 2010; Singgih, 2007).

Data Departemen Perindustrian dan Perdagangan RI, populasi usaha kecil terus bertambah dari tahun ke 
tahun disertai dengan bertambahnya tenaga kerja yang bekerja di sektor ini. Kenyataan ini menyebabkan usaha kecil dan menengah secara strategis memiliki peranan penting di Indonesia terutama dalam meningkatkan perekonomian desa (Hafni \& Rozali, 2015; Liana, 2008).

Pemberdayaan Masyarakat desa tidak lain adalah membangun masyarakat mandiri dan memahami untuk memanfaatkan kemampuan Sumber Daya Manusia (SDM) yang dikolaborasikan dengan sumber daya lingkungan Desa (Endah, 2020). Tujuan bersama membangun pemberdayaan masyarakat desa sebagai satu kesatuan dengan melibatkan berbagai pihak untuk mengusahakan masyarakat Mandiri yang memiliki kemampuan perencanaan pembangunan individual, terlepas dari jerat kemiskinan ekonomi, serta meningkatkan kapasitas dan kualitas kesejahteraan masyarakat (Amalia \& Syawie, 2016).

Sesuai dengan program pemerintah yang tertuang dalam PP N0 43 tahun 2014 tentang Desa, Desa Bocor Kecamatan Bulus Pesantren Kebumen mengupayakan pembinaan Ekonomi kerakyatan dengan melibatkan pihak ke tiga atau program kerjasama, pendampingan atau kemitraan dengan berbagai pihak termasuk perguruan Tinggi yang ada di Kebumen dan Luar Kebumen. Memanfaatkan hasil bumi banyaknya nira gula jawa dan tanaman jahe merah di Desa Bocor, sekelompok ibu-ibu yang diprakarsai oleh Bapak Faza Muttaqien tahun 2015 memperkenalkan Gula Jawa Jahe sebagai prodak minuman segar dan hangat. Hasil observasi dengan Bapak Faza Muttaqien untuk uji coba produksi pertama hanya $5 \mathrm{~kg}$ gula jawa jahe. Hasil produk pertama diberikan dengan cuma-cuma (gratis) di lingkungan Desa Bocor, keluarga, teman bahkan majelis taklim ibu-ibu dan bapak-bapak di Desa Bocor Kecamatan Bulus Pesantren Kebumen. Respon konsumen yaitu sebagian besar suka dengan rasa dan aromanya. Dari tes pemasaran konsumen Bapak Faza
Muttaqien dibantu lima orang ibu-ibu Dukuh Ragayudan RT 02 RW 02 Desa Bocor Desa Bulus Pesantren Kabupaten Kebumen Jawa Tengah. Dalam memulai bisnis gula jawa jahe hingga tahun 2019 ini, produksi Gula Jawa Jahe dalam 1 bulan mampu menjual $100 \mathrm{Kg}$. Pemasaran gula jawa jahe yang dikemas dalam plastik kecil dan dimasukan ke papper bag diberi label "Gula Jawa Jahe Familo" telah beredar di toko dan warung di kabupaten kebumen. Produk Jahe Familo juga ditawarkan melalui media sosial/WhatsApp.

Untuk mencapai standar produksi yang disyaratkan Standar Nasional Indonesia (SNI) diperlukan kemampuan Sumber Daya manusia (SDM) dan Tata kelola produksi gula jawa jahe yang komprehensif, berkaitan dengan itu upaya berbagai pihak dapat membantu melakukan pendidikan, pelatihan, pendampingan dan pembinaan terhadap produksi Gula Jawa Jahe Familo di Desa Bocor Kebumen Jawa Tengah. Salah satu pihak yang potensial adalah Perguruan Tinggi (PT), dimana dalam PT banyak cendekiawan muda yang siap untuk berbagi ilmu kepada generasi penerusnya dan masyarakat (Raharjo, 2010).

Universitas Islam Indonesia (UII) terutama Jurusan Statistika dan Pendidikan Kimia Fakultas Matematika dan Ilmu Pengetahuan Alam (FMIPA) merupakan salah satu pihak yang strategis untuk melakukan pengabdian. Selain itu kegiatan ini sejalan dengan Visi UII yakni terwujudnya UII sebagai rahmatan lil 'alamin, memiliki komitmen pada kesempurnaan (keunggulan), risalah Islamiyah, di bidang pendidikan, penelitian, pengabdian masyarakat dan dakwah, setingkat universitas yang berkualitas di negara-negara maju, termasuk melakukan pengabdian masyarakat dengan melakukan pendampingan kemitraan manajemen tata kelola Produksi Gula Jawa Jahe Familo di Dukuh Ragayudan RT 02 RW 02 Desa Bocor Kecamatan Bulus Pesantren Kabupaten Kebumen, Jawa Tengah. 
Permasalahan yang mendasar yang dihadapi oleh pengusaha Gula Jawa Jahe Familo adalah pemasarannya hanya terbatas di warung dan toko kecil dengan sistem titipan. Kemudian pengusaha juga belum mampu memaksimalkan pemasaran dengan sistem online dan belum memiliki website toko (Argawan et al., 2019). Hal ini menjadi salah satu penyebab sulitnya home industry Gula Jawa Jahe Familo berkembang dengan pesat khususnya dalam pemasaran.

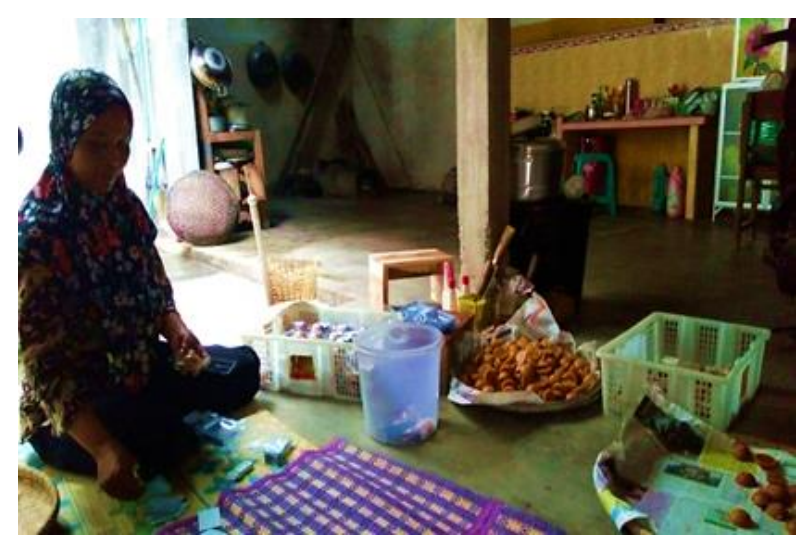

Gambar 1. Home Industry Gula Jawa Jahe Familo

Berdasarkan penjelasan di atas, maka tujuan pengabdian kepada masyarakat ini adalah untuk meningkatkan manajemen dan tata kelola home industry Gula Jawa Jahe Familo Dukuh Ragayudan Desa Bocor Kecamatan Bulus Pesantren melalui pelatihan dan pendampingan manajemen pemasaran dengan sistem e-commerce. Pemanfaatan teknologi informasi dalam menjalankan bisnis perdagangan atau sering dikenal dengan istilahecommerce bagi perusahaan kecil dapat memberikan fleksibilitas dalam produksi, memungkinkan pengiriman ke pelanggan lebih cepat untuk produk perangkat lunak, mengirimkan dan menerima penawaran secara cepat dan hemat, serta mendukung transaksi cepat tanpa kertas. Penetrasi smartphone kepada seluruh lapisan masyarakat dan sudah dilengkapi dengan akses internet membuat perkembangan e-commerce semakin pesat (Widagdo, 2016). Target dari pengabdian kepada masyarakat yaitu home industry Gula Jawa Jahe Familo dapat melakukan manajemen tata kelola, keuangan, pemasaran dan jaringan yang berkembang dengan memanfaatkan sistem e-commerce melalui pembuatan website.

\section{METODOLOGI}

Kegiatan pengabdian kepada masyarakat ini dilaksanakan di Dukuh Ragayudan RT 02 RW 02 Desa Bocor Kecamatan Bulus Pesantren Kabupaten Kebumen, Jawa Tengah dari bulan April hingga Juli 2019. Metode yang digunakan dalam pelaksanaan pengabdian kepada masyarakat ini adalah sebagai berikut.

\section{Observasi Lapangan}

Observasi lapangan dilakukan oleh tim secara intensif dalam rangka menggali informasi tentang permasalahan-permasalahan yang dihadapi masyarakat khususnya di Kebumen, Jawa Tengah. Kemudian dari berbagai permasalahan dipilih sebuah tema sebagai fokus kegiatan tim pengabdian kepada masyarakat. Kegiatan ini yang kemudian diharapkan turut serta membantu dan mendampingi masyarakat agar lebih berkualitas dan mendapatkan solusi dari permasalahan yang dihadapi.

\section{Penjajakan Kerjasama}

Menjajaki kerjasama dengan stakeholder, pengusaha, dan perguruan tinggi setempat.

3. Pendampingan Partisipatif

Pendampingan partisipatif yang dipadu dengan workshop lapangan merupakan proses pendidikan dengan transfer keilmuan terhadap peserta pengabdian kepada masyarakat yang nara sumbernya akan diisi oleh para pakar dibidangnya dan peserta aktif mengikuti kegiatan praktek langsung. Setelah melakukan pola ini akan menghasilkan produk pendidikan, tidak hanya 
memiliki keilmuan produksi suatu barang/produk yang berstandar tetapi mampu mempraktekan pada wilayah yang nyata.

\section{Pelaksanaan Inti Kegiatan}

Pelaksanaan inti kegiatan fokus kepada memberikan pemahaman dan pelatihan kepada masyarakat dalam memanajemen pemasaran gula jawa jahe yang benar dan tepat sasaran. Perincian untuk materi pelaksanaan kegiatan dapat dilihat pada Tabel I.

Tabel I. Rincian Materi Pelaksanaan Pengabdian kepada Masyarakat

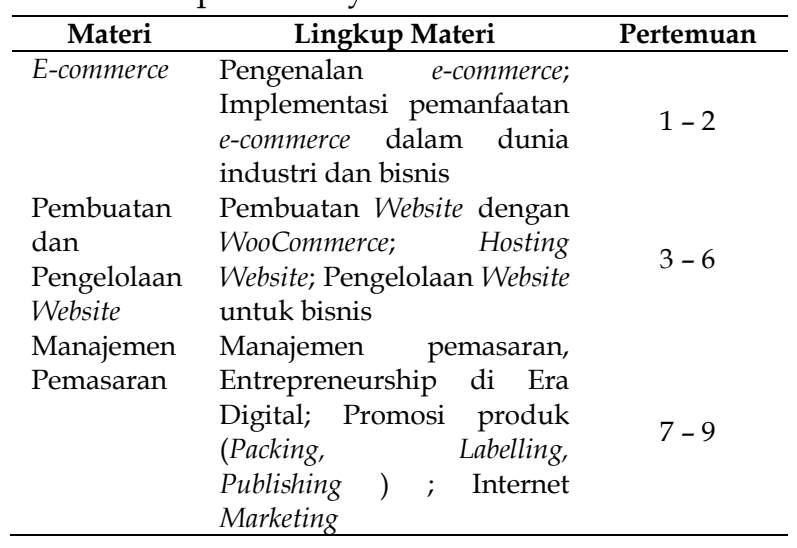

\section{HASIL DAN PEMBAHASAN}

Program kegiatan pengabdian kepada masyarakat dilaksanakan melalui beberapa tahapan, yaitu tahapan persiapan, tahapan pelaksanaan serta tahapan evaluasi.

\section{Tahapan Persiapan}

Pada tahapan persiapan, tim pengabdian kepada masyarakat melakukan observasi lapangan dan penjajakan kerjasama dengan stakeholder, pengusaha, dan perguruan tinggi setempat.

Awalnya, tim pengabdian kepada masyarakat melakukan kerjasama dengan Perguruan Tinggi IAINU (Institut Agama Islam Nahdlatul Ulama) Kebumen dan kelompok UMKM Kebumen dalam melakukan observasi lapangan secara intensif hampir satu tahun selama tahun 2018. Kegiatan pengabdian selama di wilayah Kebumen tidak hanya bersentuhan kepada kompentensi sebagai akademisi ilmu statistik dan kimia tetapi melakukan observasi terhadap masyarakat Kebumen sebagai misi perguruan tinggi UII. Hasil observasi pada awal bulan Januari 2019 hingga bulan Februari 2019 ditemukan permasalahan-permasalahan baik dalam bidang ekonomi, budaya, sosiologi, pendidikan dan agama yang mengharuskan insan akademi turut serta membantu dan mendampingi masyarakat terutama dalam memberikan solusi atas berbagai permasalahan.

Salah satu hasil temuan dari berbagai permasalahan di Kebumen, tim pengabdian kepada masyarakat menemukan adanya usaha-usaha desa yang apabila dikerjakan secara profesional, komprehensif oleh Sumber Daya Manusia (SDM) yang handal serta mempunyai tata kelola yang baik dengan memanfaatkan sistem marketing online, maka dapat menjadi mata pencaharian yang baik dan mampu menyerap tenaga kerja terutama di desa. Tim pengabdian kepada masyarakat berkeinginan menjadikan salah satu kecamatan yang terletak di pesisir selatan sebagai Desa Binaan Perguruan Tinggi UII Yogyakarta. Untuk itu tim memulainya dengan melakukan kegiatan Pengabdian kepada Masyarakat pada Usaha Gula Jawa Jahe Familo karena memiliki potensi besar menjadi pengusaha profesional bagi masyarakat di Dukuh Ragayudan RT 02 RW 02 Desa Bocor Kecamatan Bulus Pesantren Kabupaten Kebumen, Jawa Tengah.

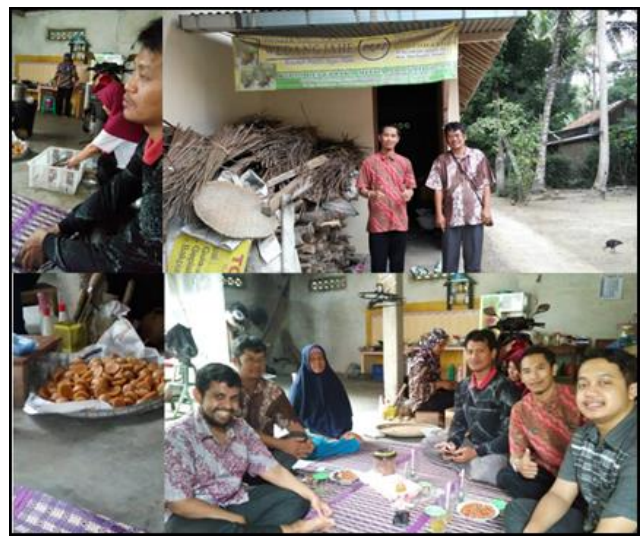

Gambar 2. Hasil Observasi Lapangan 


\section{Tahapan Pelaksanaan}

Pada tahapan pelaksanaan, tim pengabdian kepada masyarakat melakukan pendampingan partisipatif dan pelaksanaan inti kegiatan.

Pendampingan partisipatif dan pelaksanaan inti kegiatan yang dipadu dengan workshop lapangan merupakan proses transfer keilmuan terhadap peserta pengabdian kepada masyarakat yang narasumbernya diisi oleh para pakar dibidangnya dan peserta aktif mengikuti kegiatan praktek langsung. Berikut proses pendampingan partisipatif dan pelaksanaan inti kegiatan dalam memanajemen pemasaran gula jawa jahe yang telah dilakukan berdasarkan rancangan materi oleh tim pengabdian kepada masyarakat.

\section{Pelatihan dan Pendampingan tentang E-Commerce}

Tim pengabdian kepada masyarakat pada proses ini memberikan peserta pelatihan tentang bagaimana memulai bisnis di era digital dengan memanfaatkan sistem e-commerce dan bagaimana implementasi $e$ commerce dalam dunia industri dan bisnis.

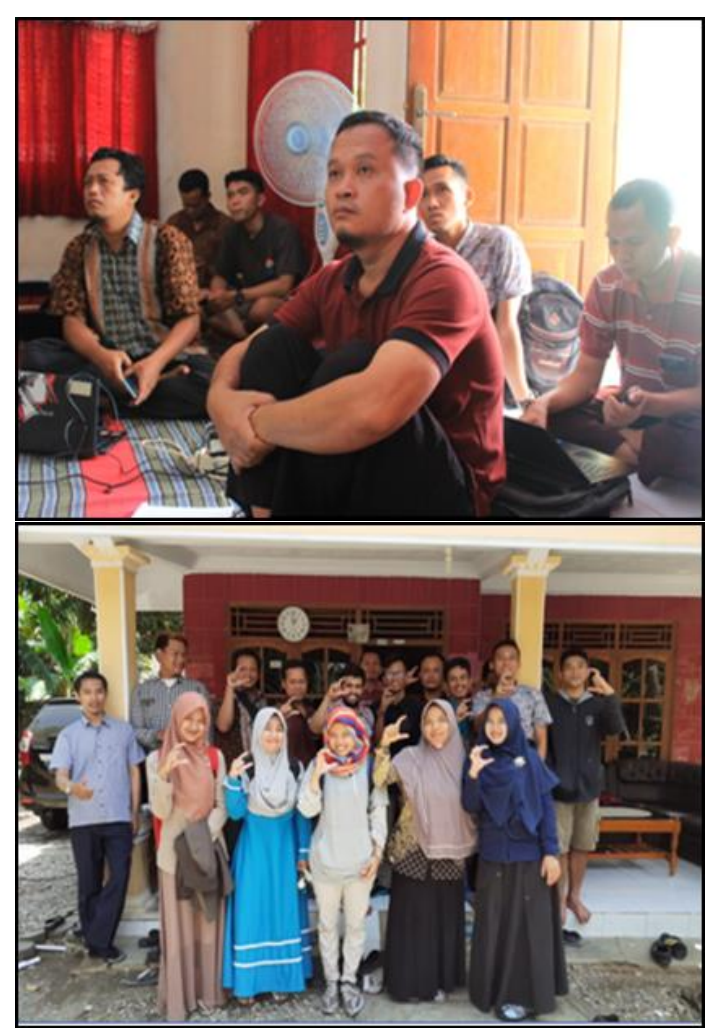

Gambar 3. Peserta Pelatihan E-Commerce

\section{Pelatihan Pembuatan dan Pengelolaan Website}

Pada proses ini peserta pengabdian kepada masyarakat melakukan praktik langsung langkah-langkah pembuatan dan pengelolaan database konsumen, pembuatan website dengan WooCommerce, Hosting website, dan pengelolaan website dalam bisnis. Hasil pelatihan pembuatan website ini adalah tim pengabdian kepada masyarakat membeli domain dan hosting untuk home industry Gula Jawa Jahe Familo. Domain website home industry Gula Jawa Jahe Familo yaitu https://familocorporation.com/

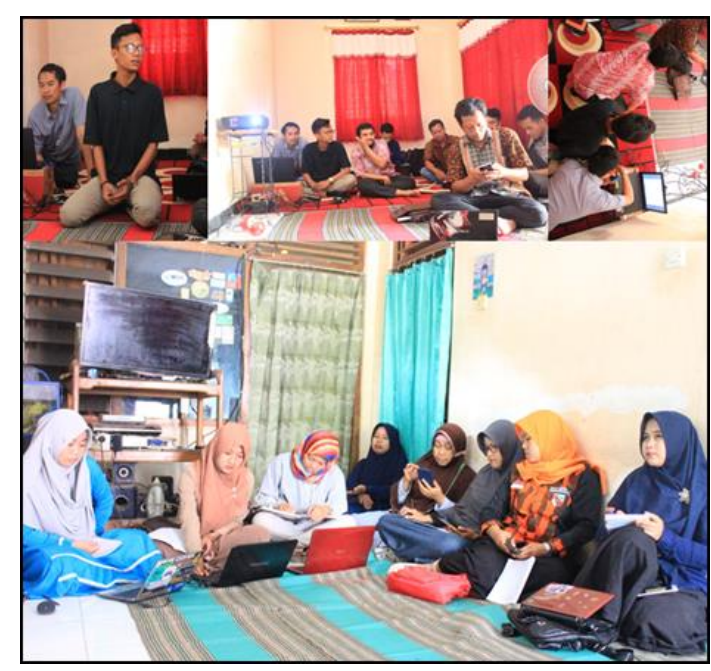

Gambar 4. Pelatihan Pembuatan Website

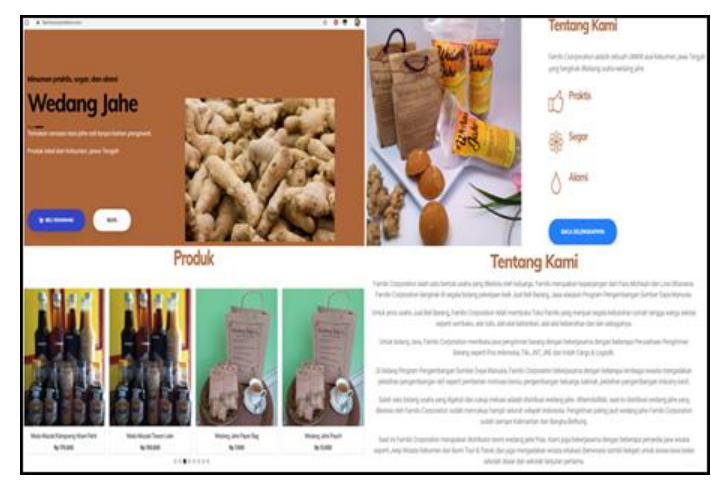

Gambar 5. Tampilan Website Gula Jawa Jahe Familo

Workshop Manajemen Pemasaran

Workshop manajemen pemasaran dilaksanakan sebagai bekal ilmu bagi peserta pengabdian kepada masyarakat tentang strategi memasarkan produk gula jawa jahe di 
era digital sekarang, strategi promosi produk gula jawa jahe, dan berbisnis dengan metode internet marketing.

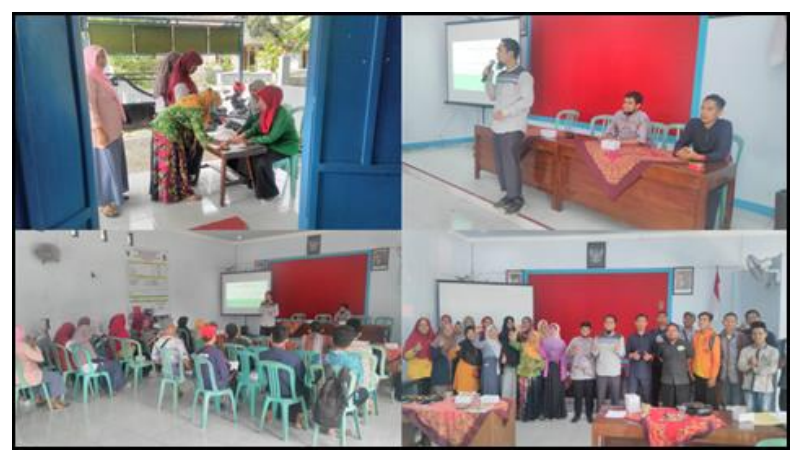

Gambar 6. Workshop Manajemen Pemasaran

\section{KESIMPULAN}

Berdasarkan pada kegiatan pengabdian masyarakat yang telah dilakukan di Desa Bocor Kecamatan Bulus Pesantren Kabupaten Kebumen, Jawa Tengah dapat disimpulkan bahwa pelatihan tentang bisnis di era digital dengan memanfaatkan sistem e-commerce dan implementasi e-commerce dalam dunia industri dan bisnis berjalan lancar dan peserta sangat antusias dalam mengikuti kegiatan tersebut. Disamping itu, Pelatihan pembuatan website sangat bermanfaat bagi peserta karena dapat menunjang dalam promosi usaha bisnis Gula Jawa Jahe Familo.

\section{UCAPAN TERIMA KASIH}

Ucapan terimakasih disampaikan kepada 1) seluruh warga Dukuh Ragayudan RT 02 RW 02 Desa Bocor Kecamatan Bulus Pesantren Kabupaten Kebumen, Jawa Tengah yang telah mendukung terlaksananya kegiatan pengabdian kepada masyarakat, 2) kelompok UMKM Kebumen yang telah berpartisipasi aktif dalam kegiatan pengabdian kepada masyarakat, 3) Direktorat Penelitian dan Pengabdian Masyarakat (DPPM) UII yang telah membiayai pelaksanaan pengabdian kepada masyarakat.

\section{REFERENSI}

Amalia, A.D., Syawie, M. 2016. Pembangunan Kemandirian Desa Melalui Konsep Pemberdayaan: Suatu Kajian Dalam Perspektif Sosiologi. Sosio Informa. 1(2):175-188. https://doi.org/10.33007/inf.v1i2.146

Argawan, B., Halim, B., Wijaya, J., Ekaputri, K., Aditia, K.C., Prasetya, N.R., Candra, T., Yuliati, R. 2019. Pemanfaatan Digital Marketing Channel Dalam Upaya Memperluas Pemasaran Produk Jahe Merah Instan Sarongge. Jurnal Pemberdayaan Masyarakat Indonesia (JPMI). 1(1):1-16.

Endah, K. 2020. Pemberdayaan Masyarakat: Menggali Potensi Lokal Desa. Moderat: Jurnal Ilmiah Ilmu Pemerintahan. 6(1):135-143. http://dx.doi.org/10.25157/moderat.v6i1.33 19

Hafni, R., Rozali, A. 2015. Analisis Usaha Mikro, Kecil, Dan Menengah (UMKM) Terhadap Penyerapan Tenaga Kerja di Indonesia. Ekonomikawan: Jurnal Ilmu Ekonomi dan Studi Pembangunan. 15(2):77-96. https://doi.org/10.30596/ekonomikawan.v1 5i2.1034

Liana, L. 2008. Pembinaan Dan Pengembangan Usaha Kecil Sebagai Sarana Memperkokoh Struktur Perekonomian Nasional. Jurnal Bisnis dan Ekonomi. 15(2):98-106.

Prihatin, S.D. 1997. Pengembangan Sumber Daya Manusia Suatu Kebijakan. Jurnal Ilmu Sosial dan Ilmu Politik (JSP). 1(1):73-97. https://doi.org/10.22146/jsp.11181

Raharjo, S.B. 2010. Pendidikan Karakter Sebagai Upaya Menciptakan Akhlak Mulia. Jurnal Pendidikan dan Kebudayaan. 16(3):229-238. https://doi.org/10.24832/jpnk.v16i3.456

Singgih, M.N. 2007. Strategi Penguatan Usaha Mikro Kecil Menengah (UMKM) Sebagai Refleksi Pembelajaran Krisis Ekonomi Indonesia. Jurnal Ekonomi Modernisasi. 3(3):218-227.

Sulistyo. 2010. Pengembangan Usaha Kecil Dan Menengah Dengan Basis Ekonomi Kerakyatan Di Kabupaten Malang. Jurnal Ekonomi Modernisasi. 6(1):58-73. 
Tambunan, T. 2002. Usaha Kecil dan Menengah di Indonesia. Jakarta: PT. Salemba Empat Patria.

Widagdo, P.B. 2016. Perkembangan Electronic Commerce (eCommerce) di Indonesia. Yogyakarta: Universitas Gadjah Mada Press. 